Research note

\title{
Pennsylvanian biota of the Sierra Agua Verde, Sonora, Mexico: biostratigraphic and paleogeographic considerations ${ }^{\text {th }}$
}

\author{
Biota del Pensilvánico de la sierra Agua Verde, Sonora, México: consideraciones bioestratigráficas \\ y paleogeográficas \\ Blanca E. Buitrón-Sánchez ${ }^{\mathrm{a}, *}$, Omar Chacón-Wences ${ }^{\mathrm{b}}$, Daniel Vachard ${ }^{\mathrm{c}}$, \\ Juan José Palafox-Reyes ${ }^{\mathrm{d}}$, José Carlos Jiménez-López ${ }^{\mathrm{e}}$, Francisco Sour-Tovar ${ }^{\mathrm{f}}$ \\ a Departamento de Paleontología, Instituto de Geología, Universidad Nacional Autónoma de México, Circuito de la Investigación Científica, Delegación \\ Coyoacán, 04510 México D.F., Mexico \\ ${ }^{\mathrm{b}}$ División de Ingeniería en Ciencias de la Tierra, Facultad de Ingeniería, Universidad Nacional Autónoma de México, Av. Universidad 3000, \\ Ciudad Universitaria, Delegación Coyoacán, 04510 México D.F., Mexico \\ ${ }^{\mathrm{c}}$ Université Lille 1, UMR 8217 Géosystèmes, 59655 Villeneuve d'Ascq Cédex, France \\ d Departamento de Geología, Universidad de Sonora, Boulevard Luis Encinas y Rosales s/n, Col. Centro, 83000 Hermosillo, Sonora, Mexico \\ e Posgrado de Ciencias de la Tierra, Universidad Nacional Autónoma de México. Cd. Universitaria, Delegación Coyoacán, 04510 México D.F., Mexico \\ ${ }^{\mathrm{f}}$ Museo de Paleontología, Facultad de Ciencias, Universidad Nacional Autónoma de México, Circuito Exterior s/n, Delegación Coyoacán, 04510 México D.F., \\ Mexico
}

Received 9 January 2014; accepted 1 December 2014

Available online 6 June 2015

\begin{abstract}
The marine biota from the middle Pennsylvanian outcrops of the Sierra Agua Verde, located in mid-eastern Sonora, consists of phylloid algae of the genera Komia and Eugonophyllum and a number of invertebrates. These species include bioaccumulations of chaetetids; brachiopods of the genera Dielasma sp., Reticulariina sp., Anthracospirifer sp., Antiquatonia sp.; bryozoans of the genus Thamniscus; tabulate corals such as Syringopora and solitary corals such as Zaphrentis; fusulinid foraminifera such as Pseudostaffella, Eoshubertella texana, Fusulinella llanoensis, and Zellerella; gastropods of the genus Euomphalus and Donaldina; and the crinoid genera Cyclocaudex, Cyclocrista, Heterosteleschus, Lamprosterigma, Mooreanteris, Pentagonopternix, Preptopremium, Cycloscaspus, and Pentaridica. The material was collected from outcrops in the first $512 \mathrm{~m}$ of the La Joya Formation, and their sediments have a total thickness of $780 \mathrm{~m}$ and consist of limestone interbedded with calcareous mudstone and sandstone lenses. The age of the middle Pennsylvanian strata corresponds to that of the Atokan stage (311 million years). The species assemblages are typical of a shallow tropical marine benthos. The analysis of the distribution of the species allowed for the determination of their paleogeographic relationships with the components of the biota of the Carboniferous strata of Texas and Kansas in the United States of America, which belong to the province of the North American Craton.

All Rights Reserved (C) 2015 Universidad Nacional Autónoma de México, Instituto de Biología. This is an open access item distributed under the Creative Commons CC License BY-NC-ND 4.0.
\end{abstract}

Keywords: Carboniferous; NW Sonora; Pennsylvanian; Upper Paleozoic

\section{Resumen}

La biota marina procedente de afloramientos del Pensilvánico medio de la sierra Agua Verde localizada en la región centro este de Sonora, está conformada por algas filoides de los géneros Komia y Eugonophyllum,por numerosos invertebrados entre ellos bioacumulaciones de chaetétidos,

\footnotetext{
* Corresponding author.

E-mail address: blancab@unam.mx (B.E. Buitrón-Sánchez).

Peer Review under the responsibility of Universidad Nacional Autónoma de México.
} 
braquiópodos de los géneros: Dielasma sp., Reticulariina sp., Anthracospirifer sp., Antiquatonia sp., briozoarios fenestélidos del género Thamniscus, corales tabulados como Syringopora y solitarios como Zaphrentis, foraminíferos-fusulínidos entre ellos Pseudostaffella, Eoshubertella, Fusulinella, Zellerella, gasterópodos de los géneros Euomphalus y Donaldina, y numerosos géneros de crinoideos Cyclocaudex, Cyclocrista, Heterosteleschus, Lamprosterigma, Mooreanteris, Pentagonopternix, Preptopremium, Cycloscaspus, Pentaridica. El material fue recolectado en afloramientos de los primeros $512 \mathrm{~m}$ de la formación La Joya, cuyos sedimentos tienen un espesor total de $780 \mathrm{~m}$ y están formados por caliza intercalada con lodolita calcárea y lentes de arenisca. La edad de los estratos corresponde al Pensilvánico Medio (Atokano) con una antigüedad de 311 millones de años. La tanatocenosis es típica del bentos de mares tropicales someros. El análisis de la distribución de las especies permitió establecer relaciones paleogeográficas con componentes de la biota del Carbonífero de Texas y Kansas en los Estados Unidos de Norteamérica, pertenecientes a la provincia del Cratón Norteamericano.

Derechos Reservados (C) 2015 Universidad Nacional Autónoma de México, Instituto de Biología. Este es un artículo de acceso abierto distribuido bajo los términos de la Licencia Creative Commons CC BY-NC-ND 4.0.

Palabras clave: Carbonífero; NO de Sonora; Pensilvánico; Paleozoico Superior

The Paleozoic rocks of Sonora consist of carbonate rocks from a warm, shallow marine environment. These rocks are believed to be between approximately 250 and 540 million years old and contain a diverse biota composed of phylloid algae, fusulinid foraminifera, sclerosponges, corals, bryozoans, brachiopods, and crinoids. Relatively few studies of the Pennsylvanian inner shelf of the Sierra Agua Verde have been conducted (Peiffer, Echevarría, Salas, \& Rangin, 1980). Previous research includes the publications of Almazán-Vázquez, BuitrónSánchez, Vachard, Mendoza-Madera, and Gómez-Espinosa (2007); Buitrón-Sánchez, Almazán-Vázquez, Vachard, and Gómez-Espinosa (2006); Buitrón-Sánchez, Gómez-Espinosa, Almazán-Vázquez, and Vachard (2007); Mendoza-Madera, Almazán-Vázquez, Buitrón-Sánchez, and Vachard (2004); Stewart, Madrid, Poole, and Kernet (1988); Stewart, Poole, and Roldán (1990) and Stewart et al. (1999). The abundance and variety of the biota have been the subjects of paleontological study (Gómez-Espinosa, 2010; Ochoa-Camarillo \& Sosa-León, 1993).

The State of Sonora is located in northwest Mexico and is bordered on the north by the United States of America, on the east by the State of Chihuahua, on the south by the State of Sinaloa, and on the west by the Gulf of California and the State of Baja California. The state's geographic coordinates are latitude $32^{\circ} 29^{\prime} \mathrm{N}, 26^{\circ} 17^{\prime} \mathrm{S}$; longitude $108^{\circ} 25^{\prime} \mathrm{E}, 115^{\circ} 03^{\prime} \mathrm{W}$ (Fig. 1). The Sierra Agua Verde falls within the following coordinates: latitude $29^{\circ} 19^{\prime} \mathrm{N}$ and longitude $109^{\circ} 56^{\prime} \mathrm{W}$, latitude $29^{\circ} 19^{\prime} \mathrm{N}$ and longitude $109^{\circ} 49^{\prime} \mathrm{W}$, latitude $29^{\circ} 10^{\prime} \mathrm{N}$ and longitude $109^{\circ} 55^{\prime}$ $\mathrm{W}$, and latitude $29^{\circ} 10^{\prime} \mathrm{N}$ and longitude $109^{\circ} 46^{\prime} \mathrm{W}$. The area is located $110 \mathrm{~km}$ north-east of the state capital of Hermosillo (Fig. 1).

The geology of the Paleozoic era in the mid-eastern region of Sonora is characterized by a calcareous platform and basinal siliciclastic deposits (Ochoa-Camarillo \& Sosa-León, 1993) spanning the interval from the Cambrian to the Permian (Stewart, \& Poole, 2002). The fossil biota comes from the limestone and shale of the La Joya formation, found in the outcrops of La Joya and Agua Caliente that form parts of the Sierra Agua Verde, which have thicknesses of approximately 294 and $780 \mathrm{~m}$, respectively. The lower contact of the bed is contiguous with the Santiago formation, and the upper contact is formed by a normal fault with the Tuntunude formation. The base of this

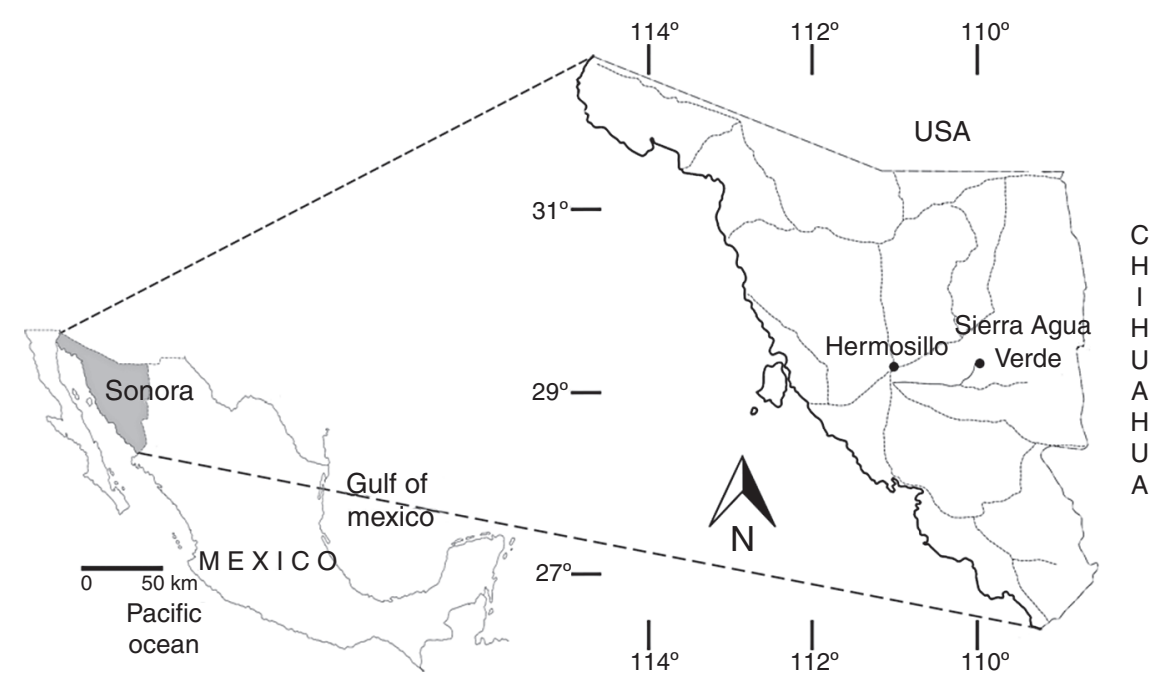

Figure 1. Location of the Sierra Agua Verde (Almazán-Vázquez et al., 2007). 
formation mainly consists of fossiliferous limestone in thick to medium strata, sandstone, mudstone, and lenses of sandstone and chert. Limestone is found throughout the entire sequence but occurs mainly in its lower portion, where it is light gray to reddish-brown color and forms medium-to-thick bands to massive levels with thin layers of interbedded calcareous mudstone. The limestone also features black and red chert nodules on its weathered surface and gray chert nodules on its fresh surface. The stratification of the limestone is gradual. At the sequence's base, it ranges from thick to massive strata with chert nodules and lenses. This portion of the sequence can be seen in the western foothills of La Joya. Next, there is a block of limestone, light gray on its unexposed surface and blue-gray on its weathered surface, which contains interbedded calcareous mudstone of a reddish color in strata of up to $3 \mathrm{~m}$ in thickness, with small quartz crystals occurring in the mudstone. Present in both the limestone and the mudstone are tabulate corals of the genus Syringopora and numerous plates and columnar fragments of crinoids of the genera Pentaridica, Pentagonopternix, Cyclocaudex, Mooreanteris, Lamprosterigma, Cyclocrista, Preptopremnum, Heterosteleschus, and Cycloscapus, as well as the shell remnants of gastropods and fenestellid bryozoan colonies. The upper part of the sequence consists of limestone strata of medium thickness, interbedded with calcareous mudstones, nodular chert, and lenses. The limestone is a light gray to reddish-brown color on its weathered surface and a light to dark gray on its fresh surface, the mudstone is a reddish-brown color, and on both the weathered and fresh surfaces, the nodular chert and lenses are white to reddish-brown with small bands of dark color; sandstone lenses and nodules are also present. This portion contains specimens of the bryozoan genus Thamniscus, the brachiopod genus Anthracospirifer and the sclerosponges genus Chaetetes of the middle Pennsylvanian strata.

The fossil biota comes from the limestone and shale rocks of the La Joya formation, in the outcrops of La Joya that form part of the Sierra Agua Verde, which have thicknesses of approximately $294 \mathrm{~m}$ and $780 \mathrm{~m}$, respectively (Ochoa-Camarillo \& Sosa-León, 1993). The lower contact of the bed is contiguous with the Santiago formation, and the upper contact is formed by a normal fault with the Tuntunudé formation. The base consists of fossiliferous limestone, sandstone, mudstone, and sandstone and chert lenses. The limestone exhibits gradual stratification. At the sequence's base, it ranges from thick to massive strata with chert lenses and nodules. This portion of the sequence can be seen in the western foothills of La Joya. Next, there is a block of limestone with interbedded calcareous mudstone; the mudstone contains small quartz crystals. Present in both the limestone and the mudstone are tabulate corals and numerous plates and columns of crinoids, as well as the fragment shells of gastropods and fenestellid bryozoans. The upper part consists of limestone with interbedded calcareous mudstones, chert nodules, and lenses strata (Fig. 2).

The biota identified in the La Joya formation contains algae of the genera Eugonophylum and Komia (Figs. 3 and 4), fusulinid foraminifera of the species Fusulinella llanoensis Thompson, 1935 (Fig. 5); Zellerella sp. (Fig. 6); Chaetetes sp. (Figs. 7-9); Syringopora sp (Fig. 10), and solitary corals such as Lophophyllidium sp., (Figs. 11-12), and fenestellid briozoans

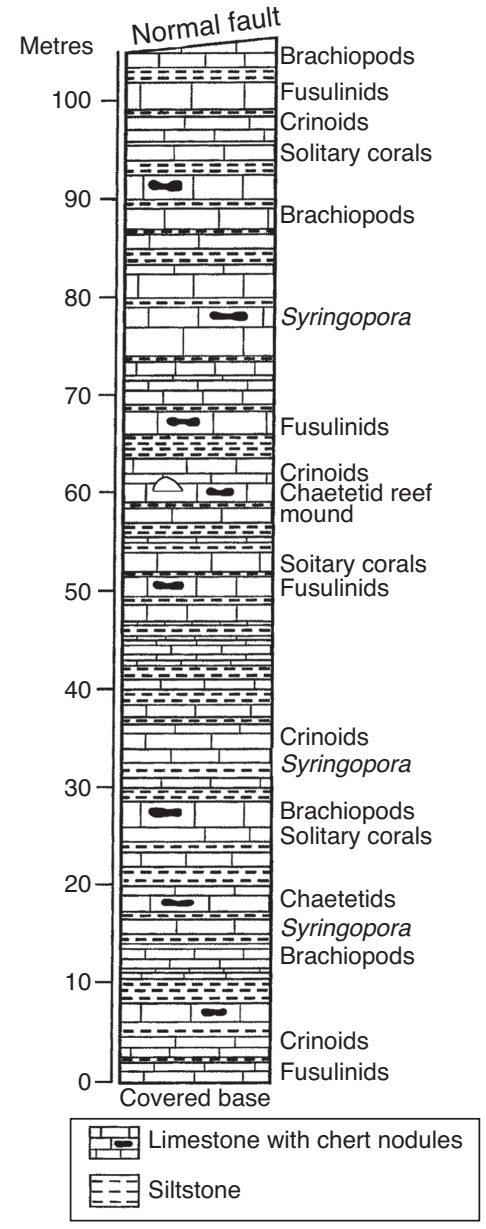

Figure 2. Stratigraphic column of the La Joya formation in Sierra Agua Verde (from Ochoa-Camarillo \& Sosa-León, 1993).

of the genus Thamniscus (Fig. 13). Brachiopods are represented by the species Reticulariina sp., (Fig. 14), Dielasma sp. (Fig. 15), Anthracospirifer sp. (Fig. 16), Antiquatonia sp., (Fig. 17). Two gastropods were identified: Straparollus (Euomphalus) sp. (Fig. 18), and Donaldina cf. D. robusta (Stevens, 1858) (Fig. 19). The crinoids are widely represented by numerous plates and columnar fragments from the species Pentagonopternix insculptus Moore \& Jefords, 1968 (Fig. 20), (21) Pentaridica simplicis Moore \& Jeffords, 1968 (Fig. 21); (22) Cyclocaudex sp. (Fig. 22), Mooreanteris waylandensis Moore \& Jefords, 1968 (Fig. 23), Lamprosterigma mirificum Moore \& Jefords, 1968 (Fig. 24), Cyclocrista martini Moore \& Jefords, 1968 (Fig. 25), Preptopremnum rugosum Moore \& Jefords, 1968 (Fig. 26), Preptopremnum leave Moore \& Jefords, 1968 (Fig. 27), Heterostelechus keithi Moore \& Jefords, 1968 (Fig. 28). Reconstruction of biotopes (Fig. 29)

Paleogeographic considerations of the Paleozoic centraleastern region. The Sonoran territory was located southwest of the Laurentian continent and south of the Equator during the middle-late Paleozoic era. Sedimentary facies occur in the mid-eastern region and predominantly consist of a calcareous platform with basinal siliciclastic deposits. 


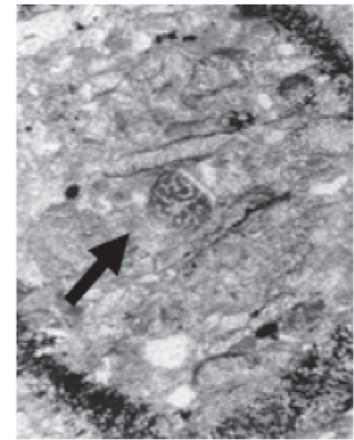

Figure 3

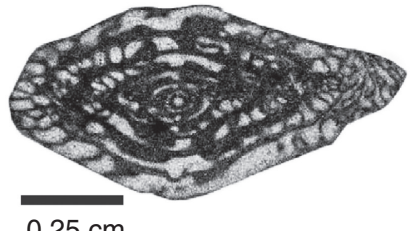

Figure 5

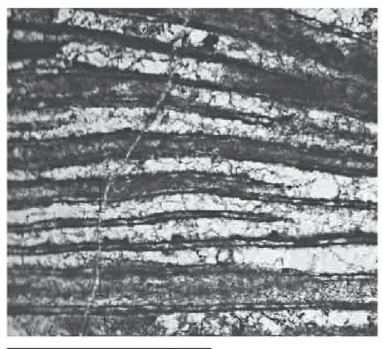

$0.1 \mathrm{~cm}$

Figure 7

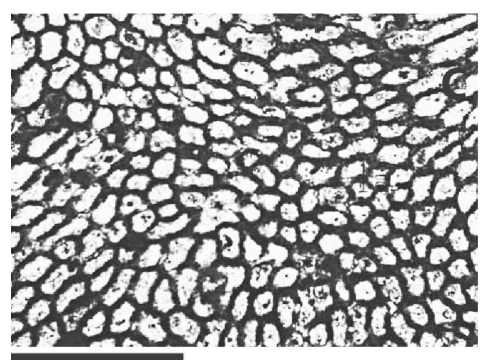

$0.1 \mathrm{~cm}$

Figure 9

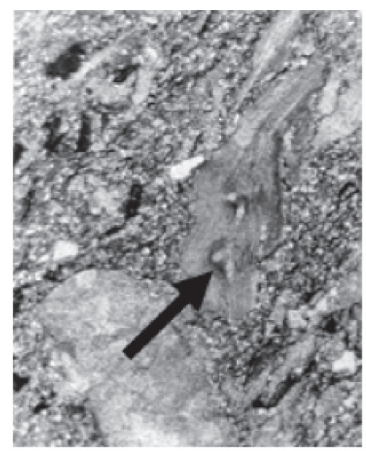

Figure 4

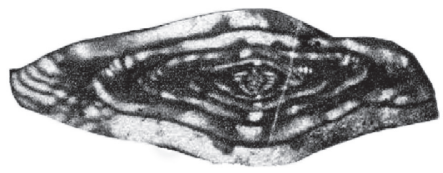

$0.25 \mathrm{~cm}$

Figure 6

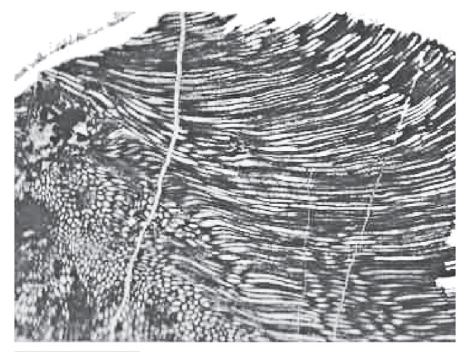

$1 \mathrm{~cm} \quad$ Figure 8

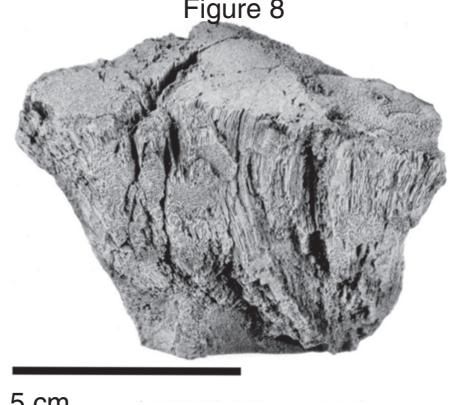

Figure 10

Figures 3-10. (3) Eugonophyllum sp.; (4) Komia sp.; (5) Fusulinella llanoensis Thompson, 1935; (6) Zellerella sp.; (7-10): Chaetetes sp.: (7) view of the colony; (8) microscopic view of the longitudinal section, and (9) microscopic view of transverse section; (10) lateral view.

The limestone sequences are outcrops of rocks whose ages range from the Cambrian to the early Permian. Since the year 2000, interest in the mid-eastern region of Sonora has increased, particularly for the Sierra Agua Verde, as shown by the studies of Buitrón-Sánchez, Almazán-Vázquez, and Vachard (2004); Buitrón-Sánchez, Almazán-Vázquez, Vachard, Gómez-Espinosa, and Mendoza-Madera (2005), and MendozaMadera et al. (2004). The algae, fusulinids, and sponges of the Pennsylvanian strata in Sonora show an affinity with the biota of Arizona, New Mexico, Texas, and California, USA. A possible connection between Mexico and the Ural Mountains and/or the Paleo-Tethys (Ocean) has been reported previously by Buitrón-Sánchez, Vachard, Almazán-Vázquez, and PalafoxReyes (2012), Vachard, Flores-de Dios, Buitrón-Sánchez, and Grajales-Nishimura (2000), Vachard, Flores-de Dios, Pantoja, Buitrón-Sánchez, Arellano, and Grajales-Nishimura (2000), and Vachard, Vidaurre-Lemus, Fourcade, and Requena (2000).

The regional geodynamic problem in Sonora is simplified, as the assemblages are similar between the North American Craton and the Caborca land form (González-León, 1989; Sedlock, 


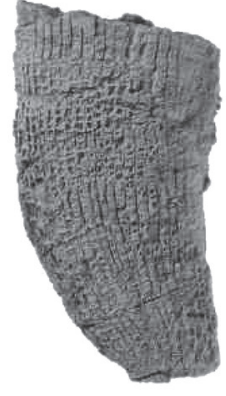

Figure 11

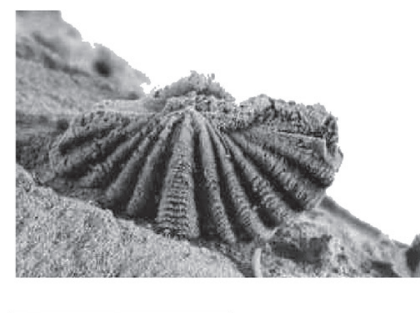

Figure 14

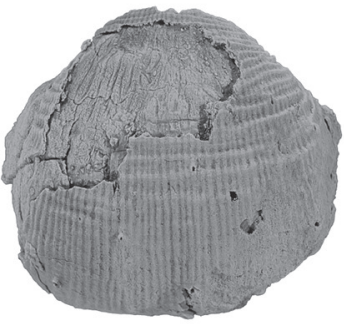

Figure 17

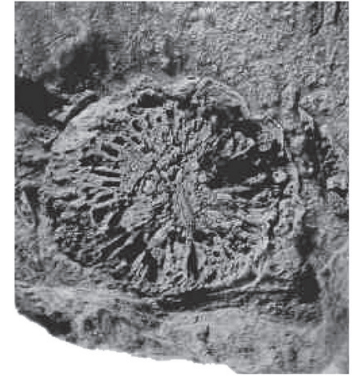

Figure 12

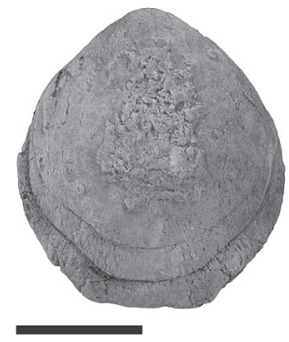

Figure 15

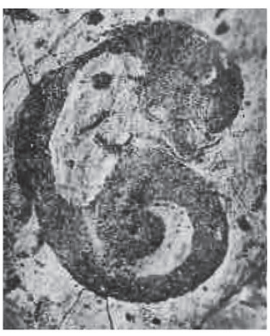

Figure 18

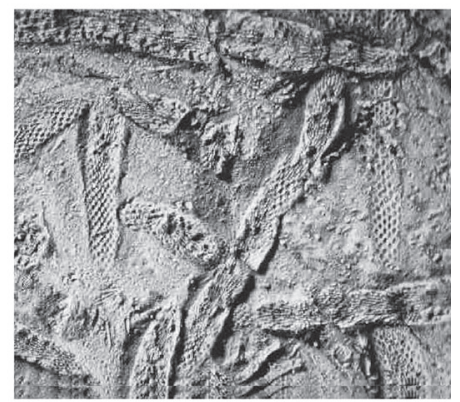

Figure 13

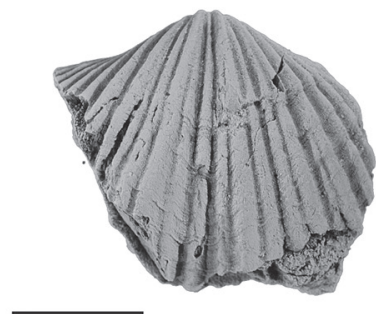

Figure 16

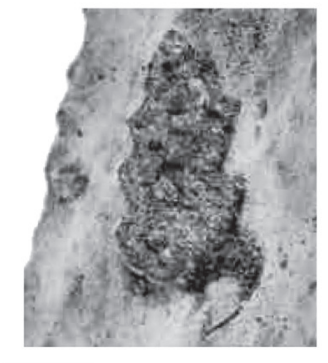

Figure 19

Figures 11-19. (11-12) Lophophyllidium sp, longitudinal (11) and transversal (12) views; (13) Thhamniscus sp.; (14) Reticulariina sp.; (15) Dielasma sp.; (16) Anthacospirifer sp.; (17) Antiquatonia sp.; (18) Straparollus (Euomphalus) sp.; (19) Donaldina cf. D. robusta (Stevens, 1858).

Ortega-Gutierrez, \& Speed, 1993). The North American Craton was separated from Gondwana and South America by a remnant of the Rheico Ocean, where some land was tectonostratigraphically separated by carbonated platforms such as the Mixteco and Oaxaquia platforms while a number of basins were developed in the middle parts of Mexico (Almazán-Vázquez et al., 2007; Buitrón-Sánchez et al., 2007; Gómez-Espinosa, Vachard, Buitrón-Sánchez, Almazán-Vázquez, \& MendozaMadera, 2008) (Fig. 30).

Paleozoic marine outcrops of Mexico are rare compared to terrestrial extensions, as these formations are often covered by a thick sequence of Mesozoic and Cenozoic sediments. However, there are a number of localities where these sedimentary Carboniferous marine rocks, containing crinoid fossils of the Mississippian and Pennsylvanian, are exposed. In Mexico, these areas are found in the northern states of Sonora and Tamaulipas, in the central states of Hidalgo and Puebla, and in the southern states of Guerrero, Oaxaca, and Chiapas. The biota identified in the La Joya formation contain algae of 2 genera, Eugonophylum and Komia; fusulinid foraminifera of the species Pseudostaffella sp., E. texana, F. llanoensis, and Zellerella sp.; sclerosponges of the genus Chaetetes; tabulate corals such as Syringopora and solitary corals such as Lophophyllidium sp., and fenestellid bryozoans of the genus Thamniscus. The brachiopods are represented by the species Dielasma sp., Reticulariina sp., Anthracospirifer sp., Antiquatonia sp.; 2 genera of gastropods were also identified, Euomphalus and Donaldina. The crinoids are widely represented by numerous columns and articulated plates of the genera Pentaridica, Pentagonopternix, Cyclocaudex, Mooreanteris, Lamprosterigma, 


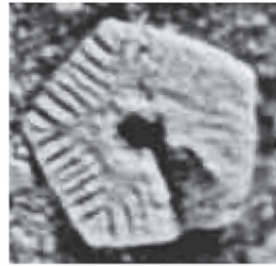

$0.25 \mathrm{~cm}$

Figure 20

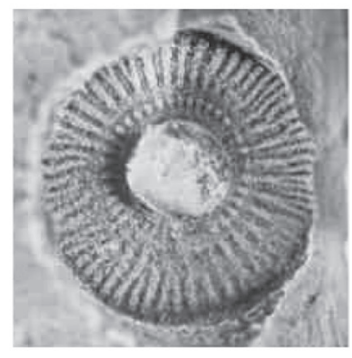

$0.5 \mathrm{~cm}$

Figure 23

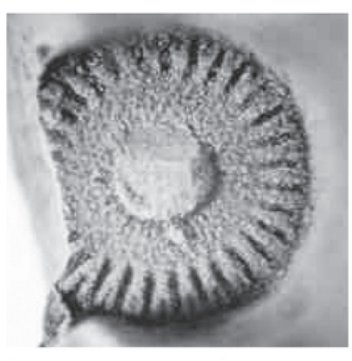

$0.25 \mathrm{~cm}$

Figure 26

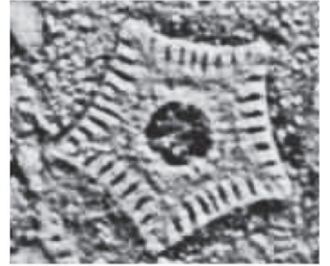

$0.25 \mathrm{~cm}$

Figure 21

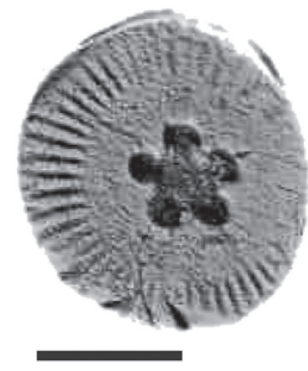

Figure 24

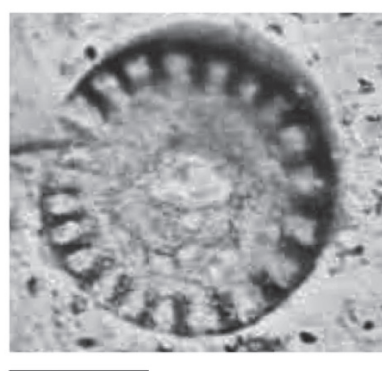

$0.25 \mathrm{~cm}$

Figure 27

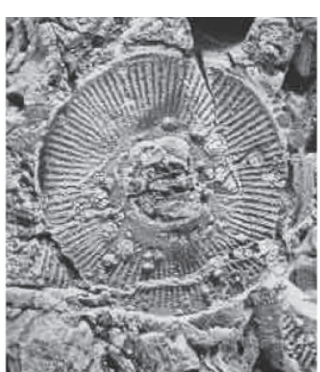

$1 \mathrm{~cm}$

Figure 22

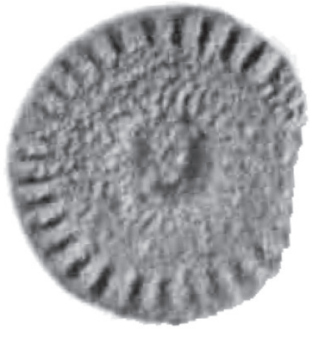

$0.25 \mathrm{~cm}$

Figure 25

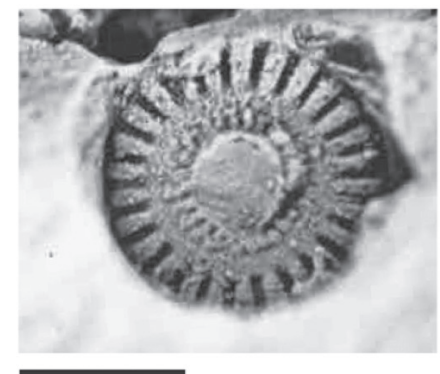

$0.25 \mathrm{~cm}$

Figure 28

Figures 20-28. (20) Pentagonopternix insculptus Moore \& Jefords, 1968; (21) Pentaridica simplicis Moore \& Jeffords, 1968; (22) Cyclocaudex sp.; (23) Mooreanteris waylandensis Moore \& Jefords, 1968; (24) Lamprosterigma mirificum Moore \& Jefords, 1968; (25) Cyclocrista martini Moore \& Jefords, 1968; (26) Preptopremnum rugosum Moore \& Jefords, 1968; (27) Preptopremnum leave Moore \& Jefords, 1968; (28) Heterostelechus keithi Moore \& Jefords, 1968.

Cyclocrista, Preptopremnum, Heterosteleschus, and Cycloscapus. The exact locations of these genera can be seen in the stratigraphic column. The present study relates the age of the layers that contain the biota of the Sierra Agua Verde, Sonora, to the stratigraphic index layers of Kansas, Colorado, and Texas in the United States of America. The age of the Sonoran strata corresponds to that of the Atokan stage, the floor of the Upper Pennsylvanian strata, which is 311 million years old. The specimens of the species comprising the biota found in the outcrop deposits occurred close to the coast, as interpreted by the presence of organisms that typically inhabited the shallow, warm waters of a coastal marine environment.

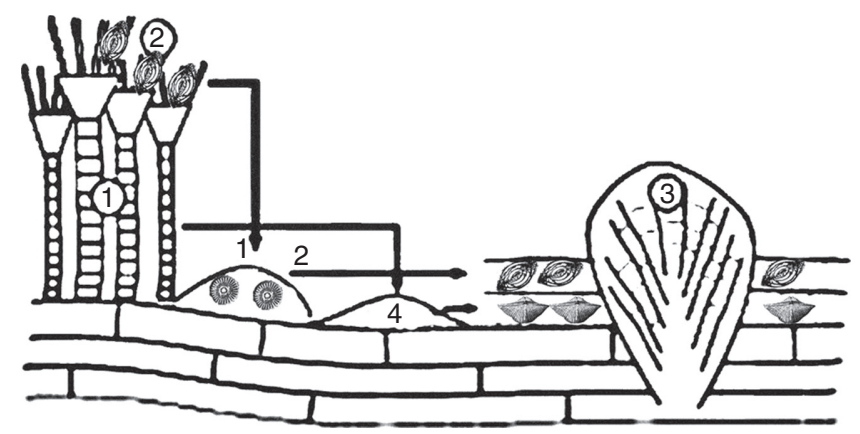

Figure 29. Reconstruction of biotopes of crinoids (1) fusulinids (2) and chaetetids (3). 


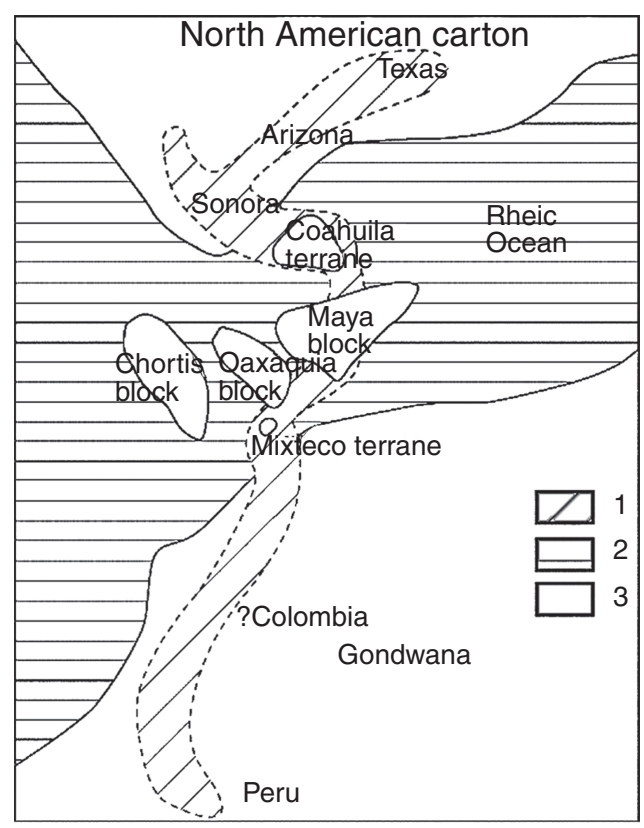

Figure 30. Paleogeographic reconstruction showing the connection between Sonora, the North American Craton (Arizona, Texas) and South American domain through different Mexican terrains (Coahuila, Maya, Mixteco, and Oaxaquia). 1, Carbonate platforms; 2, flysch basins; 3, islands and continents (Gómez-Espinosa et al., 2008).

\section{Acknowledgements}

This paper is a contribution of the Projects Conacyt No. 165826, UNAM DGAPA-PAPIIT No. 105012, and ECOS No. M13U01. The authors are particularly grateful to Departamento de Geología, Universidad de Sonora. This paper is dedicated to the memory of Dr. Emilio Almazán Vázquez who died in 2010, and who did much to further the knowledge of the Paleozoic geology of Sonora.

\section{References}

Almazán-Vázquez, E., Buitrón-Sánchez, B. E., Vachard, D., Mendoza-Madera, C., \& Gómez-Espinosa, C. (2007). The late Atokan (Moscovian, Pennsylvanian) chaetetid accumulations of Sierra Agua Verde. Sonora (NW Mexico), composition, facies and paleoenvironmental signals. In J. J. Álvaro, M. Aretz, F. Boulvain, A. Munnecke, D. Vachard, \& E. Vennin (Eds.), Paleozoic reefs and bioaccumulations: Climatic and evolutionary controls (pp. 189-200) (p. 275). London: Geological Society, London, Special Publications.

Buitrón-Sánchez, B. E., Almazán-Vázquez, V.E., \& Vachard, D. (2004). Benthic invertebrates of Carboniferous-Permian age from Sonora: Their paleogeographic implications. In 32th International Geological Congress. Florencia: APAT - Italian Agency for the Environmental Protection and Technical Services.

Buitrón-Sánchez, B. E., Almazán-Vázquez, V. E., Vachard, D., GómezEspinosa, C., \& Mendoza-Madera, C. (2005). Crinoides pensilvánicos asociados a facies "arrecifales" de chaetétidos en sierra Agua Verde, Estado de Sonora, México. Boletín Informativo. Época II, 25. Ensenada: Unión Geofísica Mexicana A. C.-CICESE.
Buitrón-Sánchez, B. E., Almazán-Vázquez, V. E., Vachard, D., \& GómezEspinosa, C. (2006). Carboniferous crinoids from Mexico and their biogeographic significance. In Kölner Forum für Geologie und Paläontologie Carboniferous Conference (p. 16). Program and Abstracts. Cologne: Köln University.

Buitrón-Sánchez, B. E., Gómez-Espinosa, C., Almazán-Vázquez, E., \& Vachard, D. (2007). A late Atokan regional encrinite (early late Moscovian, middle Pennsylvanian) in the Sierra Agua Verde, Sonora State, NW Mexico. In J. J. Álvaro, M. Aretz, F. Boulvain, A. Munnecke, D. Vachard, \& E. Vennin (Eds.), Paleozoic reefs and bioaccumulations: Climatic and evolutionary controls (p. 275). London: Geological Society, London, Special Publications.

Buitrón-Sánchez, B. E., Vachard, D., Almazán-Vázquez, E., \& Palafox-Reyes, J. (2012). Una secuencia cratónica del Carbonífero al Pérmico inferior expuesta en los cerros El Tule, noreste de Sonora, México. Revista Mexicana de Ciencias Geológicas, 29, 39-62.

Gómez-Espinosa, C. (2010). Análisis tafonómico y taxonomía del macrobentos calcáreo del Paleozoico Tardío de sierra Agua Verde, Sonora, México (Ph.D. thesis). México, DF: Instituo de Geología, Universidad Nacional Autónoma de México.

Gómez-Espinosa, C., Vachard, D., Buitrón-Sánchez, B. E., Almazán-Vázquez, E., \& Mendoza-Madera, C. (2008). Pennsylvanian fusulinids and calcareaus algae from Sonora (northwestern Mexico), and their biostratigraphic and palaeobiogeographic implications. Palevol, 7, 259-268.

González-León, C. (1989). Evolución de terrenos mesozoicos en el noroeste de México. Boletín del Departamento de Geología de la Universidad de Sonora, 6, 39-54.

Mendoza-Madera, C., Almazán-Vázquez, E., Buitrón-Sánchez, B. E., \& Vachard, D. (2004). Bioestratigrafía de la secuencia del Pensilvánico en la sierra Agua Verde, en la porción central del estado de Sonora. In XXIX Semana Cultural, Resúmenes (p. 9). Hermosillo: Universidad de Sonora.

Ochoa-Camarillo, A., \& Sosa-León, P. (1993). Geología y estratigrafía de la sierra Agua Verde, con énfasis en el Paleozoico (Bachelor's thesis). Hermosillo: Universidad de Sonora.

Peiffer, F., Echevarría, A., Salas, G., \& Rangin, C. (1980). Sur la presence de l'Ordovicien superieur a graptolites dans le nord-oest du Mexique. Compte Rendu Academy. Sciences. París, 290, 13-16.

Sedlock, R. L., Ortega-Gutierrez, F., \& Speed, R. C. (1993). Tectonostratigraphic terranes and tectonic evolution of Mexico. Geological Society of America, Special Paper, 278, 153.

Stewart, J., \& Poole, F. G. (2002). Inventory of Neoproterozoic and Paleozoic strata in Sonora, México. Denver: U.S. Geological Survey Open File Report.

Stewart, J., Madrid, R. J., Poole, F. G., \& Kernet, K. B. (1988). Studies of Late Proterozoic, Paleozoic, and Triassic rock in Sonora, Mexico. In E. Almazán-Vázquez, \& M. A. Fernández-Aguirre (Eds.), Segundo Simposio sobre Geología y Minería de Sonora, resúmenes (pp. 60-62). Hermosillo: Instituto de Geología, UNAM.

Stewart, J., Poole, F., \& Roldán, J. (1990). Tectonic and stratigraphy of the Paleozoic and Triasic southern margen of North America, Sonora, México. Arizona Geological Survey, Special Paper, 7, 183-202.

Stewart, J., Poole, F. G., Harris, A. G., Repetski, J. E., Wardlaw, B. R., Mamet, B. L., et al. (1999). Neoproterozoic (?) to Pennsylvanian inner-shelf, miogeoclinal strata in sierra Agua Verde, Sonora, México. Revista Mexicana de Ciencias Geológicas, 16, 35-62.

Vachard, D., Flores-de Dios, A., Buitrón-Sánchez, B. E., \& Grajales-Nishimura, M. (2000). Biostratigraphie par fusulines des calcaires carbonifères et permiens de San Salvador Patlanoaya (Puebla. Mexique). Geobios, 33, $5-33$.

Vachard, D., Flores-de Dios, A., Pantoja, J., Buitrón-Sánchez, B., Arellano, J., \& Grajales-Nishimura, M. (2000). Les fusulines du Mexique, une revue biostratigraphique et paléogéographique. Geobios, 33, 655-679.

Vachard, D., Vidaurre-Lemus, M., Fourcade, E., \& Requena, J. (2000). New Early Permian fusulinid assemblage from Guatemala. Compte Rendu Academy. Sciences. Paris, Serie. IIa, 33, 789-796. 